\title{
ANALISIS KINERJA KEUANGAN BERDASARKAN RASIO LIKUIDITAS DANRASIO PROFITABILITAS PADA PT POS INDONESIA (Persero)
}

\author{
Hilma Shofwatun ${ }^{1}$, Kosasih $^{2}$, Liya Megawati ${ }^{3 *}$ \\ 1,2,3 Fakultas Ekonomi dan Bisnis Universitas Singaperbangsa Karawang \\ *e-mail: hilmashofwatun@gmail.com
}

DiPublikasi: 01/07/2021

https://doi.org/10.22225/kr.13.1.2021.59-74

\begin{abstract}
The company's financial statements can be assessed by analyzing financial ratios. Financial ratios consist of several groups such as liquidity ratios, leverage, and profitability. This study uses secondary data obtained indirectly from the results of the financial statements of PT Pos Indonesia (Persero) with measuring instruments using liquidity ratios (Current Ratio, Quick Ratio, and Cash Ratio) and profitabilityratios (Net Profit Margin, Return On Asset, and Return On Equity). This study uses a quantitative method with a descriptive analysis model with the aim of analyzing financial ratios so that after the analysis the company can find out and be able to assess whether the value of the company's financial ratios can meetindustry standards or vice versa.

Based on the research results, the results of the financial performance appraisal at PT Pos Indonesia (Persero) experienced fluctuation or instability in the financial performance of PT Pos Indonesia (Persero).In terms of the liquidity ratio, it can be said that the current ratio and the quick ratio are not in good condition, while the cash ratio is able to reach the industry standard that has been set. Then the profitability ratio can be said to be in poor condition, so that the results of the ROA analysis do not meet industry standards, the results of the ROE analysis tend to be unstable, and the results of the NPM analysis have decreased for four years so that they do not meet industry standards and experience a significant increase during one year last in 2017.

Keywords: Financial Performance, Liquidity Ratio, Profitability Ratio.
\end{abstract}

\begin{abstract}
Abstrak
Laporan keuangan perusahaan dapat dinilai dengan menganalisis rasio keuangan. Rasio keuangan terdiridari beberapa kelompok seperti rasio likuiditas, leverage, dan profitabilitas. Penelitian ini menggunakan data sekunder yang diperoleh secara tidak langsung dari hasil laporan keuangan PT Pos Indonesia (Persero) dengan alat ukur menggunakan rasio likuiditas (Current Rasio, Quick Rasio, dan Cash Rasio) dan rasio profitabilitas (Net Profit Margin, Return On Asset, dan Return On Equity). Penelitian ini menggunakan metode kuantitatif dengan model analisis deskriptif dengan tujuan untuk menganalisis rasio keuangan sehingga setelah dianalisis perusahaan dapat mengetahui dan dapat menilai apakah nilai rasio-rasio keuangan perusahaan dapat memenuhi standar industri atau sebaliknya.

Berdasarkan hasil penelitian bahwa hasil dari penilaian kinerja keuangan pada PT Pos Indonesia (Persero) mengalami fluktuatif atau ketidak stabilan kinerja keuangan PT Pos Indonesia (Persero). Pada rasio likuiditas dapat dikatakan dalam kondisi kurang baik dengan metode Current Rasio dan Quick Rasio tidakmemenuhi standar industri, sedangkan Cash Rasio mampu mencapai standar industri yang telah ditetapkan. Kemudian pada rasio profitabilitas dapat dikatakan dalam kondisi kurang baik, sehingga hasilanalisis ROA tidak memenuhi standar industri, hasil analisis ROE cenderung tidak stabil, dan hasil analisisNPM mengalami penurunan selama empat tahun sehingga tidak memenuhi standar industri dan mengalami kenaikan yang cukup signifikan selama satu tahun terakhir di tahun 2017.
\end{abstract}

Kata Kunci : Kinerja Keuangan, Rasio Likuiditas, Rasio Profitabilitas.

\section{PENDAHULUAN}

Dewasa ini perekonomian di Indonesia telah mengalami pertumbuhan dan perkembangan yang cukup mengangumkan. Bukti dari pertumbuhan dan perkembangan itu adalah munculnya berbagai perusahaan besar dengan bermacam-macam bidang baik yang dikelola oleh swasta,

pemerintah, maupun negara. Tidak semata-mata perusahaan besar dapat tumbuh dan berkembang dengan mudah. Perusahaan yang baru berdiri dengan perusahaan yang telah lama berdiri saling menunjukkan eksistensinya untuk menjadi yang terbaik. 
Didalam pertumbuhan ekonomi yang pesat, yang diiringi dengan semakin banyaknya perusahaantak akan lepas dari resiko dan persaingan yang tentunya semakin ketat. Kondisi internal perusahaan yang buruk dan dinilai tidak sehat dapat mempengaruhi tidak efektifnya perusahaan dalam menjalankan segala macam aktivitasnya. Keadaan tersebut secara langsung menuntut perusahaan agar berlomba-lombamempertahankan eksistensinya danmemperbaiki kinerjanya.

Salah satu informasi penting yang berguna bagi suatu perusahaan adalah laporan keuangan perusahaan yang terdiri dari beberapa laporan seperti neraca dan laporan laba rugi. Analisis yang baik terhadap neraca dan laporan laba rugi dapat memberikan gambaran kemampuan yang telah dicapai maupun yang akan dicapai oleh suatu perusahaan. Hal ini disebabkan karena neraca disusun berdasarkan catatan- catatan kegiatan keuangan perusahaan dimasa lalu, dengan kata lain neraca merupakan ikhtisar kegiatan perusahaan dalam satu periode tertentu. Pos-pos yang terdapat pada neraca menggambarkan seluruh hasil kegiatan usaha perusahaan, dimana pada sisi aktiva menggambarkan jumlah harta yang dimiliki perusahaan. Sedangkan pada sisi passiva menggambarkan jumlah kewajiban dan modal perusahaan. Sehingga untuk itu diperlukan informasi yang relevan dan ditunjang dengan data yang dapat dipertanggungjawabkan validitasnya. Sehingga laporan keuangan perusahaan sangatlah penting bagi pemakai dikarenakan informasinya bergunadalam pengambilan keputusan.

Menurut Sjahrial dan Purba (2013:3), "Laporan keuangan (financial statement) dapat mengungkapkan dan menginformasikan empat aktivitas perusahaan (business) perencanaan, pendanaan, investasi, dan operasi". Adapun fungsi laporan keuangan antara lain, menyediakan informasi yang menyangkut posisi keuangan (aktiva, kewajiban, dan ekuitas), menyediakan informasi mengenai kinerja serta perubahan posisi keuangan suatu perusahaan yang bermanfaat bagi pemakai informasi akuntansi dalam pengambilan keputusan.

Dalam menganalisis laporan keuangan, biasanya menggunakan rasio keuangan. Manajer keuangan harus menyadari rasio keuangan pada dasarnya tidak memiliki nilai uang yang sebenarnya, tetapi merupakan perbandigan dua angka yang memilki nilai. Oleh karena itu, ratio keuangan hanya merupakan suatu petunjuk atau suatu indikasi mengenai kondisi keuangan suatu perusahaan, namun tidak merupakan gambaran lengkapmengenai laporan keuangan perusahaan yang bersangkutan. Mengingat hal itu, maka manajer harus berhatihati dalam melakukan penafsiran terhadap rasio keuangantersebut.

Setelah perhitungan rasio keuangan yang telah dilakukan perusahaan maka dapat diketahui baik tidaknya kinerja keuangan suatu perusahaan. Kinerja keuangan adalah usaha formal yang telah dilakukan olehperusahaan yang dapat mengukur keberhasilan suatu perusahaan dalam menghasilkan laba, sehingga dapat melihat prospek, pertumbuhan, dan potensi perkembangan baik Menurut Irham Fahmi (2014:239- 240) kinerja keuangan adalah suatu analisis yang dilakukan untuk melihatsejauhmana perusahaan telah melaksanakan dengan menggunakanaturan-aturan pelaksanaan keuangansecara baik dan benar. Cara yang dapat dilakukan perusahaan dalam menilai kinerja keuangan adalah dengan melakukan analisis laporan keuangan.

Industri jasa pengiriman tentu saja memberikan dampak positif kepada dunia usaha karena sangat membantu pendistribusian barang kepada konsumen dan pengiriman dokumendokumen yang dilakukan oleh perusahaan. Saat ini, bisnis di Indonesia sedang mengalami peningkatan terutama pertumbuhan bisnis online. Seseorang akan lebih mudah melakukan pembelian barang tanpa harus bertatap muka langsung secara fisik antar penjual dan pembeli dengan perusahaan dengan mengandalkan sumber daya yang ada. Suatu perusahaan dapat dikatakan berhasil apabila telah mecapai standar dan tujuan yang telah ditetapkan. tempat mereka yang berbeda. Pengiriman barang pun dapat dilakukan dengan menggunakan jasa kurir. Peranan jasa pengiriman sangat penting untuk meningkatkan percepatanpengiriman barang.

Perkembangan usaha dalam bidang jasa pengiriman barang atau jasa logistic di Indonesia saat ini mengalami peningkatan, hal ini terbukti 
dengan adanya kenaikan peringkat dari laporan survey Logistics Performance Index (LPI) 2014 dari 160 negara naik 6 peringkat, dari 59 ke 53 dengan persentase rata- rata $66,7 \%$. Hal tersebut terjadi karena semakin banyak masyarakat Indonesia yang menggunakan jasa pengiriman barang atau pengiriman dokumen- dokumen pada perusahaan, terbukti setiap tahunnya perusahaan yang bergerak dibidang jasa ekpedisi tersebut bertambah seperti tabel di bawah ini:

Tabel 1.

Daftar Perusahaan Ekspedisi di Indonesia

\begin{tabular}{|l|l|}
\hline No & Perusahaan Ekspedisi \\
\hline 1 & PT Pos Indonesia (Persero) \\
\hline 2 & JNE \\
\hline 3 & J\&T \\
\hline 4 & SiCepat \\
\hline 5 & Ninja Express \\
\hline 6 & TiKi \\
\hline 7 & First Logistics \\
\hline 8 & Indah Logistik \\
\hline 9 & Wahana Logistik \\
\hline 10 & Pandu Logistik \\
\hline 11 & RPX \\
\hline 12 & Cahaya Logistik \\
\hline 13 & GO-SEND dari GO-JEK \\
\hline
\end{tabular}

Sumber : www.4muda.com

PT Pos Indonesia (Persero) merupakan datang.

Badan Usaha Milik Negara (BUMN) yang bergerak di bidang jasa kurir, logistik, dan transaksi keuangan. Nama PT Pos Indonesia (Persero) secara resmi digunakan pada tahun 1995. Hingga saat ini, Pos Indonesia melaksanakan kegiatan pos dengan bertumpu kepada tiga bisnis inti yaitu, layanan pengiriman surat dan paket, jasa keuangan, logistik dan satu bisnis tambahan yaitu ritel. Didalam melaksanakan kegiatan, PT Pos Indonesia (Persero) selalu diawasi dan dimonitor oleh pemerintah, terlebihpada saat sekarang ini dimana BUMN merupakan mesin penghasil dana selain pajak.

Kinerja perusahaan PT Pos Indonesia (Persero) dari tahun ketahun selalu dimonitor dan diperhitungkan secara cermat dan teliti oleh pemerintah. Salah satu alat pengukur kinerja perusahaan adalah dengan mengadakan analisa terhadap laporan keuangan. Contoh alat analisis yang digunakan untuk mengukur kinerja tersebut adalah analisis rasio keuangan, yang khusus mencurahkan perhatian pada perhitungan rasio agar dapat mengadakan evaluasi keadaan finansial
Analisa terhadap laporan keuangan yang tedapat dalam neraca dan laba rugi yang dapat menghasilkan rasio. Namun, nilai ratio tersebut tidak akan mempunyai arti apa-apa bagi manajemen maupun bagi pihak-pihak yang berkepetingan apabila tidak diperbandingkan dengan standard yang jelas, seperti standard industri, standar kecenderungan atau standar tertentu. Sehingga atas dasar masalah yang dihadapi tersebut maka Menteri Negara Pendayagunaan Badan Usaha Milik Negara merasa perlu menetapkan suatu standard dan tata cara penilaian kinerja keuangan perusahaan yang didasarkan pada ratio-ratio keuangan. Maka terbitlah suatu surat keputusan yang mengatur hal tersebut yakni Keputusan Menteri Badan Usaha Milik Negara Nomor : Kep-100/MBU/2002 yang ditetapkan pada tanggal 04 Juni Tahun 2002 Tentang Penilaian Tingkat Kesehatan Badan Usaha Milik Negara.

PT. Pos Indonesia (Persero) didalam menjalankan aktivitasnya untuk mencapai misi perusahaan, maka diperlukan peran aktif dari semua bagian pada perusahaan yang antara lain adalah nemasaran sumber daya manusia maupun 
Analisis Kinerja Keuangan Berdasarkan Rasio Likuiditas DanRasio Profitabilitas Pada PT. Pos Indonesia

(Persero)

keuangan. Dari bidang yang ada tersebut, bidang keuangan merupakan masalah yang perlu mendapatkan perhatian secara seksama, karena secara normatif tujuan keuangan adalah memaksimumkan nilai perusahaan dan ini erat kaitannya dengan kondisi kesehatan perusahaan pada PT. Pos Indonesia (Persero). Tabel dibawah ini dapat menunjukan besaran nilai keuangan mengenai beberapa akun yang terdapat pada annual report yang sangat berpengaruh dalam maju mundurnya sebuah perusahaan yang juga dapat dijadikan rumus unuk menghitung rasio keuangan

Tabel 2.

Annual Report Likuiditas PT. Pos Indonesia (Persero)

\begin{tabular}{|c|c|c|c|c|}
\hline \multirow[t]{2}{*}{ TAHUN } & \multicolumn{4}{|c|}{$\begin{array}{l}\text { KETERANG } \\
\text { AN }\end{array}$} \\
\hline & Aktiva Lancar & Hutang Lancar & Persediaan & Kas+Setara Kas \\
\hline 2013 & Rp 4.505.230.575.840,00 & Rp 5.306.351.250.062,00 & $\mathrm{Rp}-$ & Rp 3.683.962.489.777,00 \\
\hline 2014 & Rp 3.653.956.218.826,00 & Rp 4.113.394.711.931,00 & Rp 3.447.374.225,00 & Rp 2.765.107.547.733,00 \\
\hline 2015 & Rp 3.577.442.371.698,00 & Rp 4.279.796.012.570,00 & Rp 4.504.911.740,00 & Rp 2.721.681.994.646,00 \\
\hline 2016 & Rp 3.620.142.201.161,00 & Rp 4.133.851.914.470,00 & Rp 24.111.507.292,00 & Rp 2.961.945.536.731,00 \\
\hline 2017 & Rp 3.878.650.242.775,00 & Rp 4.558.965.765.297,00 & $\mathrm{Rp} 23.508 .330 .350,00$ & Rp 2.937.722.023.706,00 \\
\hline
\end{tabular}

Sumber: Annual Report Profitabilitas PT Pos Indonesia

Tabel 3.

Annual Report Profitabilitas PT. Pos Indonesia (Persero)

\begin{tabular}{|c|c|c|c|c|}
\hline \multirow[t]{2}{*}{ TAHUN } & \multicolumn{4}{|c|}{$\begin{array}{c}\text { KETERANG } \\
\text { AN } \\
\end{array}$} \\
\hline & $\begin{array}{l}\text { LABA } \\
\text { BERSIH } \\
\text { SETELAH } \\
\text { PAJAK } \\
\end{array}$ & PENJUALAN & ASSET & $\begin{array}{l}\text { TOTAL MODAL } \\
\text { SEDIRI }\end{array}$ \\
\hline 2013 & Rp 246.371.920.422,00 & Rp 4.174.896.150.637,00 & Rp 5.742.323.527.717,00 & Rp 435.972.277.655,00 \\
\hline 2014 & Rp 359.814.156.574,00 & Rp 4.360.550.345.688,00 & Rp 5.062.240.791.848,00 & Rp 948.846.079.917,00 \\
\hline 2015 & -Rp 47.946.721.852,00 & Rp 4.568.571.885.140,00 & Rp 5.183.232.858.691,00 & Rp 903.436.846.121,00 \\
\hline 2016 & Rp 377.721.342.326,00 & $\operatorname{Rp} 4.454 .366 .106 .000,00$ & Rp 5.783.114.480.381,00 & Rp 1.649.262.565.911,00 \\
\hline 2017 & Rp 1.696.880.217.490,00 & Rp 4.328.498.974.450,00 & $\operatorname{Rp} 7.869 .168 .373 .720,00$ & Rp 3.310.201.608.424,00 \\
\hline
\end{tabular}

Sumber: Annual Report Profitabilitas PT Pos Indonesia

PT. Pos Indonesia (Persero) harus dapat memiliki nilai lebih dimata masyarakat dan tidak kehilangan pelanggan setianya dalam hal persaingan. Nama JNE, J\&T, dan TIKI kini menjadi lebih terkenal dibandingkan PT. Pos Indonesia (Persero) terlebih pada perusahaan dibidang e- commerce seperti Lazada, Zalora, Salestock, Shopee, dan lain-lain serta mayoritas website online di Indonesia mayoritas menggunakan jasa kurir JNE, J\&T, dan TIKI. bahwa PT. Pos Indonesia (Persero) dikenal sebagai jasa pengiriman surat menyurat bukan sebagai jasa pengirimanbarang, didalam penilaian keuangan suatu perusahaan sangatlah tergantung pada rasio keuangan yang ada di dalam laporan keuangan. Dengan analisa rasio maka dapat diketahui aspek-aspek likuiditas, danprofitabilitas yang akan menjawab apa yang menjadi tujuan penganalisaan laporankeuangan.

Direktur Keuangan PT. Pos Indonesia (Persero)
Eddi Santosa 
mengatakan sejak berdiri, perusahaan sangat bergantung dengan proyek pemerintah. Maka saat PT Pos Indonesia (Persero) kini tak lagi mendapatkan proyek dari pemerintah berupa pengiriman berbagai barang atau dokumen Kementerian/Lembaga secara langsung hal itu diklaim Eddi semakin memberatkan kinerja perusahaan.

Sebagaimana dilansir dalam inews.id Direktur Utama PT. Pos Indonesia (Persero), Gilarsi W. Setijono sebelumnya mengaku kesulitan mencapai target laba $\mathrm{Rp} 400$ miliar sepanjang 2018. Diperkirakan, realisasi laba PT. Pos Indonesia (Persero) tahun lalu mencapai Rp100 miliar atau 25 persen dari target.

Menurutnya, PT Pos memiliki tiga lini bisnis terbesar yaitu parsel atau pengiriman barang, jasa keuangan, dan pengiriman surat. Namun, bisnis persuratan sudah jauh menurun akibat perkembangan teknologi. Pada layanan jasa keuangan, bisnis PT. Pos Indonesia (Persero) juga tergerus akibat terbitnya aturan Otoritas Jasa Keuangan (OJK) yang mengizinkan siapapun

\section{TINJAUAN PUSTAKA \\ Pengertian Rasio Keuangan}

Menurut Fahmi, (2017:107), rasio keuangan atau financial ratio ini sangat penting gunanya untuk melakukan analisa terhadap kondisi keuangan perusahaan. Bagi investor jangka pendek dan menengah pada umumnya lebih banyak tertarik kepada kondisi keuangan jangka pendek dan kemampuan perusahaan untuk membayar dividen yang memadai. Informasi tersebut dapat diketahui dengan cara yang lebih sederhana yaitu dengan menghitung rasio-rasio keuangan yang sesuai dengan keinginan.

Secara jangka panjang rasio keuangan juga dipakai dan dijadikan sebagai acuan dalam menganalisis kondisi kinerja suatu perusahaan. Dalam penilaian suatu kondisi mikro dan makro ekonomi baik yang terjadi di tingkat domestik dan internasional.

Analisis rasio keuangan sendiri dimulai dengan laporan keuangan dasar yaitu dari neraca (balancesheet), perhitungan rugi-laba (income statement), dan laporan arus kas (cash flow statement). Perhitungan rasio keuangan akan menjadi agen bank. Dari sisi pengiriman barang, Gilarsi mengakui ada peningkatan signifikan hingga 400 persen akibat tren belanja online. Namun, bisnis utama PT. Pos Indonesia (Persero) berkutat pada pengiriman surat dan layanan jasa keuangan yang margin laba lebih besar.

Tujuan penelitian adalah rumusan kalimat yang menunjukan adanya suatu halyang diperoleh setelah penelitian. Adapun tujuan yang ingin dicapai dari penelitian ini adalah:

1 Untuk mengetahui, menganalisis, dan menjelaskan kinerja keuangan PT. Pos Indonesia (Persero) dengan menggunakan rasio likuiditas dengan metode current rasio, quick rasio, dan cash rasio.

2 Untuk mengetahui, menganalisis, dan menjelaskan kinerja keuangan PT. Pos Indonesia (Persero) dengan menggunakan rasio profitabilitas dengan metode ROA, ROE, dan NPM.

menjadi lebih jelas jika dihubungkan antara lain dengan menggunakan pola historis perusahaan tersebut, yang dilihat perhitungan pada sejumlah tahun guna menentukan apakah perusahaan membaik atau memburuk, atau melakukan perbandingan dengan perusahaan lain dalam industri yang sama.

\section{Pengertian Analisis Rasio Keuangan}

Menurut James C Van Horne (2015:104), analisis rasio keuangan adalah indeks yang menghubungkan dua angka akuntansi dan diperoleh dengan membagi satu angka dengan angka lainnya.

Pada umumnya rasio keuangan bermacammacam tergantung kepada kepentingan dan penggunaannya, begitu pula perbedaan jenis perusahaan juga dapat menimbulkan perbedaan rasio- rasionya. Salah satu metode yang dapat dilakukan untuk menganalisa laporan keuangan adalah analisis rasio. Analisis rasio adalah cara analisa dengan menggunakan perhitunganperhitungan perbandingan atas data kuantitatif yang ditujukkan dalam neraca maupun laba rugi. 
Analisis Kinerja Keuangan Berdasarkan Rasio Likuiditas DanRasio Profitabilitas Pada PT. Pos Indonesia

(Persero)

Pada dasarnya perhitungan rasio-rasio keuangan adalah untuk menilai kinerja keuangan perusahaan di masa lalu, saat ini, dan kemungkinannya di masa depan.

Menurut Fahmi (2017:109) adapun manfaat yang bisa diambil dengan dipergunakannya rasio keuangan, yaitu:

1 Analisis rasio keuangan sangat bermanfaat untuk dijadikan sebagai alat menilai kerja dan prestasi perusahaan.

2 Analisis rasio keuangan sangat bermanfaat bagi pihak manajemen sebagai rujukan untuk membuat perencanaan.

3 Analisis rasio keuangan dapat dijadikan sebagai alat untuk mengevaluasi kondisi

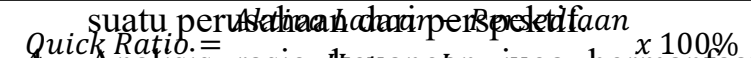

quick $R$ Aftio. $=$ rasio Hetrangam jarga bermanfaat bagi para kreditor dapat dikaitkan untuk memperkirakan potensi resiko yang akan dihadapi dikaitkan dengan adanya jaminan kelangsungan pembayaran bunga dan pengembalian pokok pinjaman.

5 Analisis rasio keuangan dapat dijadikan sebagai penilaian bagi pihak stakeholder organisasi.

\section{Jenis-jenis Rasio Keuangan}

Jenis rasio keuangan yang lazim, digunakanterdiri dari :
1. Rasio Likuiditas
Menurut Irham Fahmi (2012:174)
likuiditas merupakan gambaran

kemampuan suatu perusahaan dalam memenuhi kewajiban jangka pendeknya secara lancar dan tepat waktu sehingga likuiditas sering disebut dengan short term liquidity.

\section{a. Current ratio}

Menurut Irham Fahmi (2012:121) untuk menghitung current ratio atau rasio lancar menggunakan rumus sebagai berikut : Rasio lancar merupakan ukuran yang palingumum yang biasa digunakan untuk mengetahui kesanggupan perusahaan untuk memenuhi kewajiban jangka pendek karena rasio ini menunjukkan seberapa jauh tuntutan kreditur jangka pendek dapat dipenuhi oleh aktiva yang diperkirakan menjadi uang tunai dalam periode yang sama dengan hutang yang sudah jatuh tempo. Semakin tinggi rasio lancar, semakin besar pula kemampuan perusahaan untuk memenuhi kewajiban finansial jangka pendek. Rasio lancer adalah ukuran yang umum digunakan dalam atas solvensi jangka pendek, kemampuan suatu perusahaan memenuhi kebutuhan utang ketika jatuh tempo.

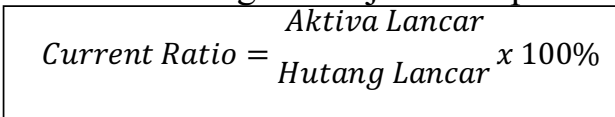

b. Quick ratio

Menurut Irham Fahmi (2012:125) untuk menghitung quick ratio atau rasio cepat menggunakan rumus sebagai berikut:

Rasio ini menunjukkan aktiva lancar yang paling likuid yang mampu menutupi hutanglancarnya. Semakin besar rasio ini semakin baik. Quick ratio adalah ukuran uji solvensi jangka pendek yang lebih teliti daripada rasio lancar karena pembilangnya melegeminasi persediaan yang dianggap aktiva lancar yang sedikit likuid dan kemungkinan menjadikan sumber kerugian

c. Cash ratio

Menurut Irham Fahmi (2012:127) untuk menghitung cash ratio atau rasio kas menggunakan rumus sebagai berikut :

Cash Ratio $=\begin{gathered}\text { Kas dan Setara Kas } \\ \text { Hutang }\end{gathered} \times 100 \%$

Dalam rasio ini yang diperbandingkan adalah kas ditambah dengan efek atau suratberharga, kas dan efek dianggap sebagai aktiva paling likuid, yang mudah dicairkan dalam jangka pendek. Semakin tinggi rasio kas berarti jumlah uang tunai yang tersediasemakin besar, sehingga pelunasan hutang terjamin.

Menurut Kasmir, (2016) melihat standar industri dari ketiga rasio tersebut adalah sebagai berikut :

Table 4.

Standar Industri untuk Rasio Likuiditas 
Analisis Kinerja Keuangan Berdasarkan Rasio Likuiditas DanRasio Profitabilitas Pada PT. Pos Indonesia

(Persero)

\begin{tabular}{|c|c|c|}
\hline & & Industri \\
\hline \multirow{3}{*}{$\begin{array}{c}\text { Likuidit } \\
\text { as }\end{array}$} & $\begin{array}{c}\text { 1. Current } \\
\text { Rasio }\end{array}$ & $2 \mathrm{kali}$ \\
\cline { 2 - 3 } & $\begin{array}{c}\text { 2. Quick } \\
\text { Rasio }\end{array}$ & $1,5 \mathrm{kali}$ \\
\cline { 2 - 3 } & 3. Cash Rasio & $50 \%$ \\
\hline
\end{tabular}

Sumber : Kasmir (2016)

2. Rasio Profitabilitas

Menurut Sutrisno (2009:16) profitabilitas adalah kemampuan perusahaan dalam menghasilkan keuntungan dengan semua modal yang bekerja di dalamnya. Menurut Kasmir, (2016:196) menyatakan bahwa rasio profitabilitasmerupakan rasio untuk menilai kemampuan perusahaan dalam mencari

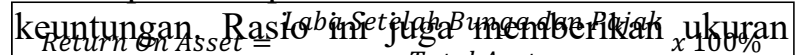
tingkat efektivitas manajeftedh $A s$ statu perusahaan. Hal ini ditunjukkan oleh laba yang dihasilkan dari penjualan danpendapatan investasi. Intinya adalah penggunaan rasio ini menunjukkan efisiensi perusahaan.

a. Net Profit Margin (Rasio Laba Bersih Setelah Pajak)

Net Profit Margin adalah rasio yang digunakan untuk menghitung sejauh mana kemampuan perusahaan dalam

menghasilkan laba bersih pada tingkat penjualan tertentu. Standar rata-rata industry untuk Net Profit Margin adalah 20\% (Kasmir, 2016).

Rasio ini dihitung dari laba bersih setelah pajak dengan penjualan. Rumusnya adalah laba bersih dibagi penjualan:

Net Profit Margin $=\begin{aligned} & \text { Lababersih setelah pajak } \\ & { } \times 100 \% }\end{aligned}$

Angka ini menunjukdkans berapargatararpensentase

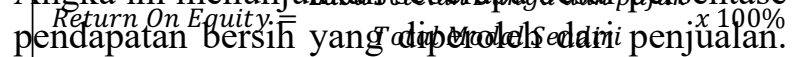
Semakin besar rasio ini semakin baik karena dianggap kemampuan perusahaan

tinggi. dalammendapatkan laba cukup

b. Return On Asset (Rasio Laba Bersih dengan Aktiva)

Return On Asset adalah Rasio yang digunakan untuk mengukur kemampuan perusahaan dalam menghasilkan laba bersih berdasarkan tingkat asset tertentu. Standar rata-rata industry untuk Return On Asset adalah 30\% (Kasmir, 2016). Return On Asset merupakan rasio terhadap laba setelah pajak. Rumus Return On Asset sebagai berikut:

Rasio ini menunjukkan seberapa besar lababersih diperoleh perusahaan bila diukur dari nilai aktiva. Menurut Kasmir, (2016:202) semakin kecil (rendah) rasio ini, maka semakin tidak baik, demikian pula sebaliknya. Artinya, rasio ini digunakan untuk mengukur efektivitas dari keseluruhan operasi perusahaan.

c. Return on Equity (ROE)

Hasil pengembalian ekuitas atau return on equity atau rentabilitas modal sendiri merupakan rasio untuk mengukur lababersih setelah pajak dengan modal sendiri. Rasio ini menunjukkan efisiensi penggunaan modal sendiri. Semakin tinggi rasio ini semakin baik. Artinya, posisi pemilik perusahaan semakin kuat, demikian pula sebaliknya (Kasmir, 2016:204). Standar rata-rata industry untuk Return On Equity adalah 40\%. Rumus untuk ROE :

Rasio ini menunjukkan berapa persen diperoleh laba bersih bila diukur dari modalpemilik.

Menurut Kasmir, (2016) melihat standar industri dari ketiga rasio tersebut adalah sebagai berikut: 
Analisis Kinerja Keuangan Berdasarkan Rasio Likuiditas DanRasio Profitabilitas Pada PT. Pos Indonesia

(Persero)

Standar Industri Untuk Rasio Profitabilitas

\begin{tabular}{|l|l|c|}
\hline Rasio & Jenis Rasio & $\begin{array}{l}\text { Standar } \\
\text { Industri }\end{array}$ \\
\hline \multirow{3}{*}{$\begin{array}{l}\text { Profitabilit } \\
\text { as }\end{array}$} & $\begin{array}{l}\text { 1. Net Profit } \\
\text { Margin }\end{array}$ & $20 \%$ \\
\cline { 2 - 3 } & $\begin{array}{l}\text { 2. Return On } \\
\text { Asset }\end{array}$ & $30 \%$ \\
\cline { 2 - 3 } & $\begin{array}{l}\text { 3. Return On } \\
\text { Equity }\end{array}$ & $40 \%$ \\
\hline
\end{tabular}

Sumber: Kasmir (2016)

\section{Kinerja Keuangan}

Pada prinsipnya kinerja dapat dilihat dari siapa yang melakukan penelitian itu sendiri. Bagi manajemen, melihat kontribusi yang dapat diberikan oleh suatu bagian tertentu bagi pencapaian tujuan secara keseluruhan. Sedangkan bagi pihak luar manajemen kinerja merupakan alat untuk mengukur suatu prestasi yang dicapai oleh organisasi dalam suatu periode tertentu yang merupakan pencerminan tingkat hasil pelaksanaan aktivitas kegiatannya, namun demikian penilaian kinerja suatu organisasi baik yang dilakukan pihak manajemen perusahaan diperlukan sebagai dasar penetapan kebijaksanaan dimasa yang akan datang.

Menurut Irham Fahmi (2012:2) Kinerja keuangan merupakan gambaran dari pencapaian keberhasilan perusahaan dapat diartikan sebagai hasil yang telah dicapai atas berbagai aktivitas yang telah dilakukan. Dapat dijelaskan bahwa kinerja keuangan adalah suatu analisis yang dilakukan untuk melihat sejauh mana suatu perusahaan telah melaksanakan dengan menggunakan aturan-aturan pelaksanaan keuangan secara baik dan benar.

Secara umum dapat dikatakan bahwa kinerja

\section{METODE PENELITIAN}

\section{Pengertian Metodologi Penelitian}

Metode yang digunakan atas penelitian ini menggunakan penelitian deskriptif kuantitatif. Penelitian deskriptif menjabarkan suatu permasalahan dan bukan bertujuan untuk membuktikan suatu teori, sedangkan kuantitatif adalah kumpulan angka-angka hasil observasi atau pengukuran. Metode ini merupakan penjabaran atas suatu permasalahan yang timbul akibat sebuah kehiiakan ataw tindakan akan keuangan adalah prestasi yang dapat dicapai oleh perusahaan dibidang keuangan dalam suatu periode tertentu yang mencerminkan tingkat kesehatan perusahaan. Disisi lain kinerja keuangan menggammbarkan kekuatan struktur keuangan suatu perusahaan dan sejauh mana asset yang tersedia, perusahaan sanggup meraih keuntungan. Hal ini berkaitan erat dengan kemampuan manajemen dalam mengelola sumber daya yang dimiliki perusahaan secara efektif dan efisien.

Menurut Irham Fahmi (2012:240) dalam buku Analisis Laporan Keuangan ada lima tahap dalam menganalisis kinerja keuangan suatu perusahaan secara umum, yaitu:

1 Melakukan review terhadap data laporan keuangan

2 Melakukan perhitungan

3 Melakukan perbandingan terhadap hasil yang diperoleh

4 Melakukan penafsiran (interpretation) terhadap berbagai permasalahan yang ditemukan.

5 Mencari dan memberikan pemecahan masalah solution terhadap berbagai permasalahan yang ditemukan.

hal tertentu dan berpengaruh pada suatu peningkatan atau penurunan jumlah angka.

Menurut Sugiyono (2011:2) metode penelitian pada dasarnya merupakan cara ilmiah untuk mendapatkan data dengan tujuan dan kegunaan tertentu. Berdasarkan hal tersebut terdapat empat kata kunci yang perlu diperhatikan yaitu cara ilmiah, data, tujuan, dan kegunaan. Cara ilmiah berarti kegiatan penelitian itu didasarkan pada ciri-ciri keilmuan yaitu rasional 
empiris, dan sistematis. Rasional berarti kegiatan penelitian itu dilakukan dengan cara-cara masuk akal, sehingga terjangkau oleh penalaran manusia. Empiris berarti cara- cara yang dilakukan itu dapat diamati oleh indera manusia, sehingga orang lain dapat mengamati dan mengetahui cara-cara yang digunakan. Sistematis artinya proses yang digunakan dalam penelitian itu menggunakan langkah-langkah tertentu yang bersifat logis.

Penelitian ini berjudul Analisis Kinerja Keuangan Berdasarkan Rasio Likuiditas dan Rasio Profitabilitas pada PT Pos Indonesia (Persero) di BUMN. Dengan memperhatikan tujuan tersebut, maka metode penelitian yang dapat digunakan adalah metode penelitian deskriptif dan pendekatan dalam penelitian ini yaitu mmenggunakan pendekatan kuantitatif.

Menurut Sugiyono, (2012:13), penelitian deskriptif yaitu penelitian yang dilakukan untuk mengetahui nilai variabel mandiri, baik satu variabel atau lebih (independen) tanpa membuat perbandingan atau menghubungkan dengan variabel lain. Tujuan dari penelitian deskriptif ini adalah untuk membuat deskripsi, gambaran, atau lukisan secara sistematis, factual dan akurat mengenai faktafakta, sifat-sifat serta hubungan antar fenomena yang diselidiki yang dilakukan dengan cara memahami kenyataan yang ada dan membandingkan dengan teori yang dipelajari oleh penulis sehingga dapat mengambil kesimpulan.

Metode penelitian kuantitatif menurut Sugiyono, (2012:8) yaitu Metode penelitian yang berlandaskan pada filsafat positivisme, digunakan untuk meneliti pada populasi atau sampel tertentu, pengumpulan data menggunakan instrument penelitian, analisis data bersifat kuantitatif/statistic, dengan tujuan untuk menguji hipotesis yang telah ditetapkan.

\section{Definisi Konseptual Analisis Rasio Keuangan}

Rasio Keuangan adalah kegiatan menganalisa laporan keuangan dengan cara membandingkan angka-angka, membagi satu angka dengan angka lainnya sehingga didapat hubungan yang relevan atas angka tersebut untuk mengetahui kondisi keuangan perusahaan yang tetap sehingga tujuan memaksimumkan kemakmuran pemegang saham dapat dicapai.

\section{Definisi Konseptual Rasio Likuiditas}

Rasio Likuiditas adalah rasio yang digunakan untuk mengukur kemampuan perusahaan dalam membayar hutang jangka pendek perusahaan. Rasio likuiditas dapat dipakai sebagai alat ukur penelitian ini terdiri dari current ratio, quick ratio, dan cash ratio.

\section{Definisi Konseptual Rasio Profitabilitas}

Rasio Profitabilitas ini digunakan untuk menunjukan tingkat efisiensi perusahaan dalam mendapatkan keuntungan. Rasio Profitabilitas yang dipakai sebagai alat ukur penelitian ini terdiri dari net profit margin, return on asset, return on equity.

\section{Definisi Konseptual Kinerja Keuangan}

Kinerja Keuangan adalah usaha formal yang telah dilakukan oleh perusahaan yang dapat mengukur keberhasilan suatu usaha dalam menghasilkan laba, sehingga dapat melihat prospek, pertumbuhan, dan potensi perkembangan dengan mengandalkan sumber daya yang ada. Suatu usaha dapat dikatakan berhasil apabila telah mencapai standard dan tujuan yang telah ditetapkan. Kinerja keuangan dapat dihitung melalui rasio keuangan yang diantaranya dapat dihitung melalui rasio profitabilitas dan rasio likuiditas.

Adapun tahapan analisis yang digunakan dalam penelitian ini adalah sebagai berikut:

1 Mengumpulkan data dan informasi yang relevan dengan tujuan penelitian.

2 Mereduksi data dengan memilih data- data yang penting dan memfokuskan pada hal-hal yang pokok.

3 Menyajikan data dalam bentuk alur penilaian kinerja keuangan yang diimplementasikan PT Pos Indonesia (Persero).

4 Membandingkan dengan standar industri rasio likuiditas dan rasio profitabilitas, sehingga dapat dilakukan evaluasi atas analisa kinerja keuangan terhadap likuiditas dan profitabilitas pada PT Pos Indonesia (Persero).

5 Setelah membandingkan data tersebut, kemudian ditarik kesimpulan dari data yang telah diteliti. 


\section{HASIL DAN PEMBAHASAN Profil PT Pos Indonesia (Persero)}

Sejarah mencatat keberadaan Pos Indonesia begitu panjang, Kantor Pos pertama didirikan di Batavia (sekarang Jakarta) oleh Gubernur Jenderal G.W Baron van Imhoff pada tanggal 26 Agustus 1746 dengan tujuan untuk lebih menjamin keamanan surat-surat penduduk, terutama bagi mereka yang berdagang dari kantor- kantor di luar Jawa dan bagi mereka yang datang dari dan pergi ke Negeri Belanda.

Selama 17 tahun berstatus Perum, maka pada Juni 1995 berubah menjadi Perseroan Terbatas dengan nama PT Pos Indonesia (Persero). Dengan berjalannya waktu, Pos Indonesia kini telah mampu menunjukkan kreatifitasnya dalam pengembangan bidang perposan Indonesia dengan memanfaatkan insfrastruktur jejaring yang dimilikinya yang mencapai sekitar 24 ribu titik layanan yang menjangkau 100 persen kota/kabupaten, hampir 100 persen kecamatan dan 42 persen kelurahan/desa, dan 940 lokasi transmigrasi terpencil di Indonesia. Seiring dengan perkembangan informasi, komunikasi dan teknologi, jejaring Pos Indonesia sudah memiliki lebih dari 3.800 Kantorpos online, serta dilengkapi electronic mobile pos di beberapa kota besar. Semua titik merupakan rantai yang terhubung satu sama lain secara solid \& terintegrasi. Sistem Kode Pos diciptakan untuk mempermudah processing kiriman pos dimana tiap jengkal daerah di Indonesia mampu diidentifikasi dengan akurat.

Pos Indonesia merupakan Badan Usaha Milik Negara (BUMN) yang bergerak di bidang jasa kurir, logistik, dan transaksi keuangan. Lebih dari 90 perusahaan kini menjalin kemitraan dengan Pos Indonesia. Mereka berasal dari berbagai sektor, seperti jasa keuangan, perbankan, listrik, air minum, pajak, hingga zakat. Tak hanya perusahaan domestik, entitas bisnis dari perusahaan global seperti UPS, Cardig International, dan Western Union pun telah menjadi mitra utama Pos Indonesia. Bahkan bagi Western Union, Pos Indonesia merupakan agen yang terpenting dan terbesar di Asia Pasifik. Untuk itu perbaikan internal senantiasa dilakukan manajemen Pos Indonesia di setiap lininya. Setidaknya ada empat bidang utama yang menjadi fokus pembenahan, yaitu manajemen sumber daya manusia dan organisasi, sistem keuangan, kapabilitas infrastruktur, dan strategi marketing. Pos Indonesia telah menerapkan sistem akuntansi berbasis enterprise resource planning yang akan menjadi backbone pencatatan transaksi bisnis perusahaan. Sedangkan dari segi perbaikan infrastruktur, PT Pos Indonesia setiap tahunnya

mengalokasikan pengembangan teknologi informasi setidaknya di atas 50 milyar rupiah, ini melanjutkan keberhasilan di tahun-tahun sebelumnya untuk terus bergerak ke masa depan PT Pos Indonesia yang lebih cerah.

\section{Analisis Standar Rasio Rata-Rata Industri}

Menilai kinerja keuangan salah satunya dengan suatu standar rasio yang layak dijadikan dasar pembanding, bila tidak ada standar yang dipakai sebagai dasar pembanding dari penafsiran rasio-rasio suatu perusahaan, penganalisisan tidak dapat menyimpulkan apakah rasio-rasio itu menunjukan kondisi yang menguntungkan atau tidak menguntungkan.

Hasil perhitungan yang dipakai dalam menganalisis rasio likuiditas dan rasio profitabilitas pada perusahaan PT Pos Indonesia (Persero) Tbk adalah sebagai berikut:

\section{Hasil Perhitungan Current Rasio}

Berikut ini adalah hasil perhitungan current rasio PT Pos Indonesia (Persero) Tbk selama limatahun terakhir.

Tabel 6.

Hasil Current Rasio PT. Pos Indonesia (Persero) Tbk

\begin{tabular}{|c|c|c|c|}
\hline Tahun & Hasil Perhitungan & Standar Industri & Keterangan \\
\hline 2013 & $0,85 \mathrm{kali}$ & $2 \mathrm{kali}$ & Tidak Memenuhi Standar Industri \\
\hline 2014 & $0,89 \mathrm{kali}$ & $2 \mathrm{kali}$ & Tidak Memenuhi Standar Industri \\
\hline 2015 & $0,84 \mathrm{kali}$ & $2 \mathrm{kali}$ & Tidak Memenuhi Standar Industri \\
\hline
\end{tabular}


Analisis Kinerja Keuangan Berdasarkan Rasio Likuiditas DanRasio Profitabilitas Pada PT. Pos Indonesia

(Persero)

\begin{tabular}{|c|c|c|c|}
\hline 2016 & 0,88 kali & 2 kali & Tidak Memenuhi Standar Industri \\
\hline 2017 & 0,85 kali & 2 kali & Tidak Memenuhi Standar Industri \\
\hline
\end{tabular}

Sumber : Olahan Peneliti, 2020

Berdasarkan tabel di atas rasio perhitungan current ratio PT Pos Indonesia (Persero) menunjukan bahwa hasil perhitungan dari current rasio di bawah standar industri sebesar 2 kali. Jika dilihat tahun 2013 hasil perhitungan current rasio yang menunjukkan bahwa aktiva lancar yang diperoleh adalah sebesar 0,85 kali dari hutang lancar tahun 2013. Pada tahun 2014 hasil perhitungan current rasio yang menunjukkan bahwa aktiva lancar yang diperoleh adalah sebesar 0,89 kali dari hutang lancar tahun 2014. Pada tahun 2015 hasil perhitungan current rasio yang menunjukan bahwa aktiva lancar yang diperoleh adalah sebesar 0,84 kali dari hutang lancar tahun 2015. Pada tahun 2016 hasil perhitungan current rasio yang menunjukan bahwa aktiva lancar yang diperoleh adalah sebesar 0,88 kali dari hutang lancar tahun 2016. Pada tahun 2017 hasil perhitungan current rasio yang menunjukan bahwa aktiva lancar yang diperoleh adalah sebesar 0,85 kali dari hutang lancar tahun 2017. Sehingga dapat disimpulkan bahwa dari 5 tahun terakhir current rasio tidak memenuhi standar industri yang telah ditetapkan. Hal ini disebabkan karena PT Pos Indonesia (Persero) Tbk memiliki jumlah hutang lancar yang lebih besar dibandingkan dengan asset lancar yang dimiliki, sehingga menunjukkan bahwa kinerja keuangan PT Pos Indonesia dinilai kurang baik dari segi asset lancar. Jika angka rasio lancar suatu perusahaan minimal dapat melebihi standar atau sama dengan standar maka perusahaan tersebut punya kemampuan yang baik dalam melunasi kewajibannya. Karena perbandingan aktivanya lebih besar dibanding kewajiban yang dimiliki. Namun, jika rasio yang dimiliki perusahaan di bawah standar maka kemampuan perusahaan dalam melunasi hutang masih dipertanyakan. Namun, jika hasil perhitungan rasio lancar lebih besar dari standar bukan berarti perusahaan dapat dikatakan memiliki keadaan keuangan yang baik, karena suatu perusahaan bisa saja tidak mengalokasikan aktiva lancarnya secara optimal, tidak memanfaatkan aktiva lancarnya secara efisien, dan tidak mengelola modalmodalnya dengan baik.

\section{Hasil Perhitungan Quick Rasio}

Berikut ini adalah hasil perhitungan quick rasio PT Pos Indonesia (Persero) Tbk selama lima tahun terakhir.

Tabel 7.

Hasil Quick Rasio PT Pos Indonesia (Persero) Tbk

\begin{tabular}{|c|c|c|c|}
\hline $\begin{array}{l}\text { Tahu } \\
\mathrm{n}\end{array}$ & Hasil Perhitungan & Standar Industri & Keterangan \\
\hline 2013 & $0,85 \mathrm{kali}$ & $1,5 \mathrm{kali}$ & Tidak Memenuhi Standar Industri \\
\hline 2014 & $0,89 \mathrm{kali}$ & $1,5 \mathrm{kali}$ & Tidak Memenuhi Standar Industri \\
\hline 2015 & $0,83 \mathrm{kali}$ & $1,5 \mathrm{kali}$ & Tidak Memenuhi Standar Industri \\
\hline 2016 & $0,87 \mathrm{kali}$ & $1,5 \mathrm{kali}$ & Tidak Memenuhi Standar Industri \\
\hline 2017 & $0,85 \mathrm{kali}$ & $1,5 \mathrm{kali}$ & Tidak Memenuhi Standar Industri \\
\hline
\end{tabular}

Sumber: Olahan Peneliti, 2020 Berdasarkan tabel di atas rasio

Berdasarkan tabel di atas rasio perhitungan quick ratio PT Pos Indonesia (Persero) menunjukan bahwa hasil perhitungan dari quick rasio di bawah standar industri sebesar 1,5 kali. Jika dilihat pada tahun 2013 hasil perhitungan quick rasio vang menuniukan bahwa aktiva lancar yang diperoleh adalah sebesar 0,85 kali darihutang lancar tahun 2013. Pada tahun 2014 hasil perhitungan quick rasio yang menunjukan bahwa aktiva lancar yang diperoleh adalah sebesar 0,89 kali dari hutang lancar tahun 2014. Pada tahun 2015 hasil perhitungan quick rasio vang 
menunjukan bahwa aktiva lancar yang diperoleh adalah sebesar 0,83 kali dari hutang lancar tahun 2015. Pada tahun 2016 hasil perhitungan quick rasio yang menunjukan bahwa aktiva lancar yang diperoleh adalah sebesar 0,87 kali dari hutang lancar tahun 2016. Pada tahun 2017 hasil perhitungan quick rasio yang menunjukan bahwa aktiva lancar yang diperoleh adalah sebesar 0,85 kali dari hutang lancar tahun 2017. Sehingga dapat disimpulkan bahwa dari 5 tahun terakhir quick rasio tidak memenuhi standar industri yang telah ditetapkan. Hal ini disebabkan karena PT Pos Indonesia memiliki jumlah hutang yang lebih besar dibandingkan dengan asset lancar yang dimiliki, sehingga menunjukkan bahwa kinerja keuangan PT Pos Indonesia dinilai kurang baik dari segi quick rasio. Jika angka quick rasio suatu perusahaan minimal dapat melebihi standar atau sama dengan standar maka perusahaan tersebut punya kemampuan yang baik dalam melunasi kewajibannya. Quick rasio atau yang biasa disebut rasio cepat biasanya dianggap sebagai tanda kekuatan atau kelemahan financial perusahaan yang digunakan untuk mengukur kemampuan perusahaan untuk memenuhi kewajiban jangka pendeknya dengan menggunakan asset yang paling liquid atau asset yang paling mendekati uang tunai (asset cepat), karena hasil quick rasio didapat dengan mengurangkan persediaan dari aktiva lancar dan sisanya dibagi dengan kewajiban lancar. Dikurangkan persediaan atau inventori dari perhitungan aktiva lancar karena persediaan pada dasarnya merupakan asset lancar yang sulit dikonversi dengan uang tunai dalam waktu singkat dan biasanya juga akan terjadi kerugian jika terjadi lukuidasi.

\section{Hasil Perhitungan Cash Rasio PT Pos Indonesia (Persero) Tbk}

Berikut ini adalah hasil perhitungan cash rasio PT Pos Indonesia (Persero) Tbk selama lima tahun terakhir.

Table 8.

Hasil Cash Rasio PT Pos Indonesia (Persero) Tbk

\begin{tabular}{|c|c|c|l|}
\hline $\begin{array}{c}\text { Tahu } \\
\mathrm{n}\end{array}$ & Hasil Perhitungan & Standar Industri & \multicolumn{1}{|c|}{ Keterangan } \\
\hline 2013 & $69 \%$ & $50 \%$ & Memenuhi Standar Industri \\
\hline 2014 & $67 \%$ & $50 \%$ & Memenuhi Standar Industri \\
\hline 2015 & $64 \%$ & $50 \%$ & Memenuhi Standar Industri \\
\hline 2016 & $72 \%$ & $50 \%$ & Memenuhi Standar Industri \\
\hline 2017 & $64 \%$ & $50 \%$ & Memenuhi Standar Industri \\
\hline
\end{tabular}

Sumber: Olahan Peneliti, 2020

Berdasarkan tabel di atas rasio perhitungan cash ratio PT Pos Indonesia (Persero) menunjukan bahwa hasil perhitungan dari cash rasio memenuhi standar industri sebesar 50\%. Jika dilihat pada tahun 2013 hasil perhitungan cash rasio yang menunjukan bahwa kas dan setara kas yang diperoleh adalah sebesar 69\% dari hutang tahun 2013. Pada tahun 2014 hasil perhitungan cash rasio yang menunjukan bahwa kas dan setara kas yang diperoleh adalah sebesar $67 \%$ dari hutang tahun 2014. Pada

tahun 2015 hasil perhitungan cash rasio yang menunjukan bahwa kas dan setara kas yang diperoleh adalah sebesar $64 \%$ dari hutang tahun 2015. Pada tahun 2016 hasil perhitungan cash rasio yang menunjukan bahwa kas dan setara kas yang diperoleh adalah sebesar $72 \%$ dari hutang tahun 2016. Pada tahun 2017 hasil perhitungan cash rasio yang menunjukan bahwa kas dan setara kas yang diperoleh adalah sebesar $64 \%$ dari hutang tahun 2017. Sehingga dapat disimpulkan bahwa dari 5 tahun terakhir cash rasio memenuhi atau bahkan melaupaui standar industri yang telah ditetapkan. Hal ini disebabkan karena PT Pos Indonesia memiliki kas dan setara kas dalam jumlah yang besar sehingga dapat menutupi hutang perusahaan. Karena PT Pos Indonesia (Persero) ini cenderung mengalokasikan dana perusahaan ke dalam kas dan setara kas dibandingkan dengan asset lancar 
lainnya. Rasio kas ini pada dasarnya penyempurnaan dari current rasio dan quick rasio yang digunakan untuk mengidentifikasi sejauh mana dana (kas dan setara kas) yang tersedia untuk melunasi kewajiban lancar. Rasio kas ini merupakan rasio likuiditas yang paling ketat terhadap kemampuan perusahaan dalam menutupi hutang hal ini dikarenakan cash rasio hanya memperhitungkan asset atau aktiva lancar yang paling likuid yaitu kas dan setara kas yang paling mudah dan cepat untuk digunakan dalam melunasi hutang lancarnya.

Sehingga dapat disimpulkan bahwa rasio likuiditas PT Pos Indonesia (Persero) Tbk dari hasil perhitungan current rasio dan quick rasio secara keseluruhan tidak memenuhi standar industri yang telah ditetapkan, berbeda dengan hasil perhitungan cash rasio yang secara keseluruhan memenuhi atau bahkan melampaui standar industri yang telah ditetapkan. Hal ini menunjukan bahwa PT Pos Indonesia (Persero) Tbk dinilai kinerja keuangannya kurang baik karena seharusnya nilai rasio likuiditas mampu menyamai standar industri atau lebih tinggi dari standar industri karena semakin tinggi nilai rasio likuiditas maka semakin tinggi juga kemampuan perusahaan menutupi kewajiban jangka pendeknya.

\section{Hasil Perhitungan Return On Asset PT Pos Indonesia (Persero) Tbk}

Berikut ini adalah hasil perhitungan return on asset PT Pos Indonesia (Persero) Tbk selama lima tahun terakhir.

Hasil Return On Asset PT Pos Indonesia (Persero) Tbk

\begin{tabular}{|l|c|c|c|}
\hline $\begin{array}{l}\text { Tahu } \\
\mathrm{n}\end{array}$ & Hasil Perhitungan & $\begin{array}{c}\text { Standar } \\
\text { Industri }\end{array}$ & Keterangan \\
\hline 2013 & $4 \%$ & $30 \%$ & $\begin{array}{c}\text { Tidak Memenuhi Standar } \\
\text { Industri }\end{array}$ \\
\hline 2014 & $7 \%$ & $30 \%$ & $\begin{array}{c}\text { Tidak Memenuhi Standar } \\
\text { Industri }\end{array}$ \\
\hline 2015 & $-1 \%$ & $30 \%$ & $\begin{array}{c}\text { Tidak Memenuhi Standar } \\
\text { Industri }\end{array}$ \\
\hline 2016 & $7 \%$ & $30 \%$ & $\begin{array}{c}\text { Tidak Memenuhi Standar } \\
\text { Industri }\end{array}$ \\
\hline 2017 & $22 \%$ & $30 \%$ & $\begin{array}{c}\text { Tidak Memenuhi Standar } \\
\text { Industri }\end{array}$ \\
\hline
\end{tabular}

Sumber: Olahan Peneliti, 2020

Berdasarkan tabel di atas perhitungan return on asset PT Pos Indonesia (Persero) menunjukan bahwa hasil perhitungan dari return on asset di bawah standar industri sebesar 30\%. Jika dilihat pada tahun 2013 hasil perhitungan ROA yaitu sebesar 4\% yang menunjukkan bahwa penghasilan bersih yang diperoleh adalah sebesar $4 \%$ dari total aktiva tahun 2013. Pada tahun 2014 hasil perhitungan ROA yaitu sebesar 7\% yang menunjukkan bahwa penghasilan bersih yang diperoleh adalah sebesar 7\% dari total aktiva tahun 2014. Pada tahun 2015 hasil perhitungan ROA yaitu sebesar $-1 \%$ yang menunjukkan bahwa penghasilan bersih yang diperoleh adalah sebesar $-1 \%$ dari total aktiva tahun 2015. Pada tahun 2016 hasil perhitungan ROA yaitu sebesar 7\% yang menunjukkan bahwa penghasilan bersih yang diperoleh adalah sebesar 7\% dari total aktiva tahun 2016. Pada tahun 2017 hasil perhitungan ROA yaitu sebesar $22 \%$ yang menunjukkan bahwa penghasilan bersih yang diperoleh adalah sebesar $22 \%$ dari total aktiva tahun 2017. Sehingga dapat disimpulkan bahwa dari 5 tahun terakhir rasio ROA tidak memenuhi standar industri yang telah ditetapkan. Itu artinya bahwa persentase keuntungan yang didapat dari total asset bernilai sangat kecil.

\section{Hasil Perhitungan Return On Equity PT Pos Indonesia (Persero) Tbk}

Berikut ini adalah hasil perhitungan return on equity PT Pos Indonesia (Persero) Tbk selama lima tahun terakhir. 
Analisis Kinerja Keuangan Berdasarkan Rasio Likuiditas DanRasio Profitabilitas Pada PT. Pos Indonesia

(Persero)

Tabel 10.

Hasil Return On Equity PT Pos Indonesia (Persero) Tbk

\begin{tabular}{|l|c|c|c|}
\hline $\begin{array}{l}\text { Tahu } \\
\mathrm{n}\end{array}$ & Hasil Perhitungan & $\begin{array}{c}\text { Standar } \\
\text { Industri }\end{array}$ & Keterangan \\
\hline 2013 & $57 \%$ & $40 \%$ & Memenuhi Standar Industri \\
\hline 2014 & $38 \%$ & $40 \%$ & $\begin{array}{c}\text { Tidak Memenuhi Standar } \\
\text { Industri }\end{array}$ \\
\hline 2015 & $-5 \%$ & $40 \%$ & $\begin{array}{c}\text { Tidak Memenuhi Standar } \\
\text { Industri }\end{array}$ \\
\hline 2016 & $23 \%$ & $40 \%$ & $\begin{array}{c}\text { Tidak Memenuhi Standar } \\
\text { Industri }\end{array}$ \\
\hline 2017 & $51 \%$ & $40 \%$ & Memenuhi Standar Industri \\
\hline
\end{tabular}

Sumber: Olahan Peneliti, 2020

Berdasarkan tabel di atas perhitungan return on equity PT Pos Indonesia (Persero) menunjukan bahwa hasil perhitungan dari return on equity cenderung di bawah standar industrisebesar 40\%. Jika dilihat pada tahun 2013 hasil perhitungan ROE yaitu sebesar 57\% yang menunjukkan bahwa penghasilan bersih yang diperoleh adalah sebesar $57 \%$ dari total modal tahun 2013. Pada tahun 2014 sampai 2016 hasil perhitungan ROE mengalami penurunan. Pada tahun 2014 hasil perhitungan ROE yaitu sebesar $38 \%$ yang menunjukkan bahwa penghasilan bersih yang diperoleh adalah sebesar 38\% dari total modal tahun 2014. Pada tahun 2015 hasil perhitungan ROE yaitu sebesar - 5\% yang menunjukkan bahwa penghasilan bersih yang diperoleh adalah sebesar $-5 \%$ dari total modal tahun 2015. Pada tahun 2016 hasil perhitungan ROE yaitu sebesar 23\% yang menunjukkan

\section{Tabel 11.}

Hasil Net Profit Margin PT Pos Indonesia (Persero) Tbk

\begin{tabular}{|l|c|c|c|}
\hline $\begin{array}{l}\text { Tahu } \\
\mathrm{n}\end{array}$ & Hasil Perhitungan & $\begin{array}{c}\text { Standar } \\
\text { Industri }\end{array}$ & Keterangan \\
\hline 2013 & $6 \%$ & $20 \%$ & $\begin{array}{c}\text { Tidak Memenuhi Standar } \\
\text { Industri }\end{array}$ \\
\hline 2014 & $8 \%$ & $20 \%$ & $\begin{array}{c}\text { Tidak Memenuhi Standar } \\
\text { Industri }\end{array}$ \\
\hline 2015 & $-1 \%$ & $20 \%$ & $\begin{array}{c}\text { Tidak Memenuhi Standar } \\
\text { Industri }\end{array}$ \\
\hline 2016 & $8 \%$ & $20 \%$ & $\begin{array}{c}\text { Tidak Memenuhi Standar } \\
\text { Industri }\end{array}$ \\
\hline 2017 & $39 \%$ & $20 \%$ & Memenuhi Standar Industri \\
\hline
\end{tabular}

Sumber: Olahan Peneliti, 2020

Berdasarkan tabel di atas perhitungan net profit margin PT Pos Indonesia (Persero)

menunjukan bahwa hasil perhitungan dari net profit margin cenderung di bawah standar industri 
sebesar 20\%. Jika dilihat pada tahun 2013 hasil perhitungan NPM yaitu sebesar 6\% yang menunjukkan bahwa penghasilan bersih yang diperoleh adalah sebesar 6\% dari penjualan tahun 2013. Pada tahun 2014 hasil perhitungan NPM yaitu sebesar $8 \%$ yang menunjukkan bahwa penghasilan bersih yang diperoleh adalah sebesar 8\% dari penjualan tahun 2014. Pada tahun 2015 hasil perhitungan NPM yaitu sebesar $-1 \%$ yang menunjukkan bahwa penghasilan bersih yang diperoleh adalah sebesar $-1 \%$ dari penjualan tahun 2015. Pada tahun 2016 hasil perhitungan NPM yaitu sebesar $8 \%$ yang menunjukkan bahwa penghasilan bersih yang diperoleh adalah sebesar $8 \%$ dari penjualan tahun 2016. Kemudian pada tahun 2017 hasil perhitungan NPM mengalami peningkatan yang cukup signifikan yaitu menjadi $39 \%$ yang menunjukkan bahwa penghasilan bersih yang diperoleh adalah sebesar 39\% dari penjualan tahun 2017. Sehingga dapat disimpulkan bahwa dari 5 tahun terakhir rasio NPM tidak memenuhi standar yang telah

\section{KESIMPULAN DAN SARAN}

Berdasarkan hasil penelitian dan pembahasan hasil penelitian mengenai "Analisis Kinerja Keuangan Berdasarkan Rasio Likuiditas dan Rasio Profitabilitas Pada PT Pos Indonesia (Persero) Tbk" yang telah diuraikan sebelumnya yang berkaitan dengan rumusan masalah dapat ditarik kesimpulan sebagai berikut:

1. Kinerja keuangan PT. Pos
Indonesia (Persero) dengan
menggunakan rasio likuiditas
dengan metode Current Ratio,
Quick Ratio, dan Cash Ratio dapat
dikatakan dalam kondisi kurang
baik. Nilai current rasio dan quick
rasio tidak memenuhi standar
industri yang telah ditetapkan
secara umum. Namun berbeda

\section{DAFTAR PUSTAKA}

Fahmi, Irham. 2013. Pengantar Manajemen Keuangan. Bandung : Alfabeta.

Fahmi, I. (2017). Analisis Laporan Keuangan (9th ed.). Alfabeta.

Harahap, Sofyan Syafri. 2011. Analisis Kritis Atas Laporan Keuangan. Jakarta :PT. Raja Grafindo Persada.

Hasibuan, Malayu S.P. 2011. Manajemen Sumber Daya ditetapkan. Itu artinya bahwa persentase keuntungan yang didapat dari penjualan dinilai masih kecil.

Sehingga dapat disimpulkan bahwa rasio profitabilitas PT Pos Indonesia (Persero) Tbk dari hasil perhitungan return on asset secara keseluruhan kurang baik atau tidak memenuhi standar industri yang telah ditetapkan, hasil perhitungan return on equity berfluktuatif atau cenderung tidak memenuhi standar industri yang telah ditetapkan, dan net profit margin juga secara keseluruhan kurang baik atau tidak memenuhi standar industri yang telah ditetapkan. Hal ini menunjukan bahwa PT Pos Indonesia (Persero) Tbk dinilai kinerja keuangannya rata-rata tidak mampu menghasilkan laba atas aktiva dan equity yang dimiliki dan juga hasil net profit margin yang masih kurang dari standar industri, yang berarti bahwa laba yang dihasilkan dari proses penjualan belum maksimal.

dengan nilai cash rasio PT Pos Indonesia (Persero) yang dapat dikatakan memenuhi standar industri yang telah ditetapkan secara umum.

2. Kinerja keuangan PT Pos Indonesia (Persero) dengan menggunakan rasio profitabilitas dengan metode return on asset, return on equity, dan net profit margin dapat dikatakan dalam kondisi kurang baik. Karena PT Pos Indonesia (Persero) nilai return on assets, return on equity, dan net profit margin tidak memenuhi standar industri yang telah ditetapkan secara umum. 
Analisis Kinerja Keuangan Berdasarkan Rasio Likuiditas DanRasio Profitabilitas Pada PT. Pos Indonesia

(Persero)

Munawir, S. 2010. Analisis Laporan Keuangan. Edisi Keempat Cetakan Kelima Belas. Yogyakarta: Liberty.

Robbins, P.Stephen dan Timothy A. Judge. 2012. Perilaku Organisasi. Salemba Empat. Jakarta.

Sutrisno. 2014. Manajemen Keuangan: Teori, Konsep, dan Aplikasi. Yogyakarta : Ekonisia.

Sutrisno, Edy. 2013. Manajemen Sumber Daya Manusia. Edisi Pertama. Jakarta : Kencana.

Sugiyono. (2012). Metode Penelitian Bisnis. Alfabeta. . 2013. Metode Penelitian Manajemen. Bandung : Alfabeta.

Thomas Sumarsan. 2013. Perpajakan Indonesia (Vol.3). Jakarta : PT. Indeks.

Sumber Jurnal

Damayanti, Umi Rachmah. 2017. Analisis Kinerja Keuangan Perusahaan BUMN Sebelum Dan Setelah Privatisasi. Jurnal. UIN Sultan SyarifKasim Riau.

Faisal, Ahmad. 2017. Analisis Kinerja Keuangan. Jurnal. Universitas Mulawarman Samarinda.

Febrianty, Fitria. 2017. Analisis Rasio Likuiditas dan Profitabilitas Pada Bank Rakyat Indonesia Syariah. Jurnal. UIN Raden Fatah Palembang.

Febriyanto, F. 2016. Analisis Rasio Keuangan Pada PT Gudang Garam Tbk Untuk menilai Kinerja Perusahaan Periode 2011-2014. Jurnal. Universitas Bina Insani.

Handayani, Dessie. 2013. Analisis Kinerja Keuangan Berdasarkan Rasio Profitabilitas Pada PT Bhimex Di Samarinda. Jurnal. Universitas Mulawarman.

Kaunang, Swita Angelina. 2013. Analisis Kinerja Keuangan Perusahaan Pada PT Cipta Daya Nusantara Manado. Jurnal. Universitas Sam Ratulangi Manado.

Khalida, Poppy Farizka dan Achmad Husaini. 2019. Analisis Laporan Keuangan Untuk Menilai Kinerja Keuangan Perusahaan (Studi Kasus Pada PT Bentoel Internasional Investama Tbk Periode 2016-2018). Jurnal. Universitas Brawijaya Malang.

Nawan, Ilham Nugroho Hanung. 2011. Analisis Kinerja Keuangan PT Pos Indonesia (Persero) Kantor Pos Solo 57100 Tahun 2009-2010. Jurnal. Universitas Sebelas Maret Surakarta.

Nurdin, Muhamad. 2015. Analisis Kinerja Keuangan Berdasarkan Rasio Profitabilitas Dan Rasio Aktivitas Pada Dinas Kebudayaan Dan Pariwisata Kabupaten Bangka. Jurnal. Universitas Bangka Belitung.

Pangemanan, Ireine Wulan, HermanKaramoy dan Meily Kalalo. 2017. Analisis Rasio Likuiditas, LeverageDan Profitabilitas Untuk Menilai Kinerja Keuangan Pada Pt.Bank Central Asia, Tbk. Cabang Manado.Jurnal. Universitas Sam Ratulangi Manado.

Suhendro, Dedi. 2017. Analisis Profitabilitas dan Likuiditas Untuk Menilai KinerjaKeuangan Pada PT Siantar Top Tbk. Jurnal. AMIK Tunas Bangsa Pematangsiantar Sumatera Utara.

Sutiman. 2019. Analisis Rasio ROA Dan ROEDalam Menilai Tingkat Kesehatan Pada PT Bank Mandiri (Persero) TbkTahun 2012 - 2017. Jurnal. Universitas Pamulang.
Wijaya, Fandi. 2017. Penggunaan Analisis Rasio Keuangan Untuk Menilai Kinerja Keuangan Badan Usaha Milik Negara (Studi Kasus Pada PT Aneka Tambang (Persero) Tbk, Yang Terdaftar Di BEI Tahun 2012 2015). Jurnal. Universitas BrawijayaMalang.

Yusa, Feby Febrianti. 2016. Analisis RasioLikuiditas Dan Rasio Profitabilitas Dalam Rangka Meningkatkan Kinerja Keuangan (Kasus Pada Perusahaan Kosmetik Dan Barang Keperluan Rumah Tangga Yang Terdaftar Di Bursa Efek Indonesia). Jurnal. Universitas Riau.

Sumber Skripsi

Amaliyah, Nurdiana. 2014. Analisis Kinerja Keuangan Pada Baitul Maal Wat Tamwil Koperasi Serba Usaha Darussalam Cabang Muhammadiyah Karawang Timur. Skripsi. Universitas Negeri Singaperbangsa Karawang.

Andaresta, Ovie. 2017. Analisis Rasio Keuangan Pada PT. Gudang Garam Tbk Periode 2012-2016. Skripsi. Universitas Sumatera Utara Medan.

Asakina, Ramadhani. 2017. Analisis KinerjaKeuangan BerdasarkanProfitabilitas Dan Likuiditas Pada PT Unilever Indonesia, Tbk Periode Tahun 2012-2016. Skripsi.Universitas Singaperbangsa Karawang.

Citrasari. 2013. Analisis Rasio Laporan Keuangan Untuk Menilai Kinerja Keuangan Pada Perusahaan DaerahAir Minum Kabupaten Karawang. Skripsi. Universitas Negeri Singaperbangsa Karawang.

Hawari, Lazuard Achmad. 2017. Analisis Perbandingan Kinerja KeuanganBerdasarkan Rasio Keuangann(Studi Pada Perusahaan Manufaktur Subsector Semen YangTerdaftar Di BEI Periode20112016). Skripsi. Universitas Singaperbangsa Karawang.

Novianti, Diny. 2017. Analisis Laporan Keuangan Dalam Menilai Kinerja Keuangan Pada Koperasi Guru Rawamerta (KOGURA) Karawang. Skripsi. Universitas Negeri Singaperbangsa Karawang.

Nugrahanti, Triana. 2015. Analisis RasioKeuangan Untuk Menilai KinerjaBUMN Pada PT Adhi Karya (Persero) Tbk. Tahun 2012-2014.Skripsi. Universitas NegeriYogyakarta.

Mawardani, Citra. 2015. Analisis Profitabilitas Untuk MengukurKinerja Keuanga PT. Pos Makassar Sebelum Dan Setelah Launching Pos Express Tahun 20082014. Skripsi. Universitas Hasanuddin Makassar.

Ridha, Muhammad. 2017. Analisis RasioKeuangan Dalam Menilai KinerjaKeuangan BUMN (Studi Kasus Pt. Perkebunan Nusantara III Medan). Skripsi. UIN SumateraUtara Medan.

Saputro, Fandy Giyono. 2014. Analisis Kinerja Keuangan Perusahaan BUMN Bidang Konstruksi Yang Terdaftar Di Bursa Efek Indonesia Periode 20102013. Skripsi. Universitas Negeri Yogyakarta. 